\title{
Headmaster Leadership Style to Improve Education Staff Competence in Public Elementary School
}

\author{
Rahmatika Quin Isnaini \\ Department of Education Management \\ Universitas Negeri Surabaya \\ Surabaya, Indonesia \\ quin.18021@mhs.unesa.ac.id
}

\begin{abstract}
Leadership Style of Headmaster to Improve Education Staff Competence in Public Elementary School. Education is something that becomes a basic need in the lives of every individuals. In education institution need a headmaster who leads the schools and personnel in institution. The ways someone who leads which focus on the specific behaviors and actions is called leadership. It's will determine the goal of the institution and certainty it will happened when the leader can cooperate with all staffs, especially education staff. Education staff must have high work loyalty and able to work together with all personal in institution. The aim of this study is to describe the headmaster leadership style to improve education staff competence in public elementary school. This study used qualitative research design. It is because this research focus on the phenomenon of headmaster leadership style to improve education staff competence. The result of this study is explaining there are a lot of leadership style. However, in this study focus on one of leadership style, that is Path leadership style to education staff. It determines this style from the action and behavior of headmaster in leading at Public Elementary School.
\end{abstract}

Keywords—education; headmaster; leadership style; education staff

\section{INTRODUCTION}

Education is something that becomes a basic need in the lives of every individuals. Education is also effort to increase someone's ability to get the next level [1]. In achieving an educational goal, it requires an educational resource that has an important role in all educational activities, certainly not separated from the role of educators and education personnel. Educator and education staff have a huge influence in improving the quality of education. In this case not only an educator and education staff to manage education [2]. There are many personnel in school to transfer knowledge to student; headmaster, teachers, and also education staff. They have their respective duties and authority, especially headmaster and education staff. When we talk about institution certainly there are two subjects, those are a leader and staffs [3].

Leader is the one who by his personality can inspire others to improve their efforts to achieve a common goal. The ways someone who leads which focus on the specific behaviors and actions is called leadership. Leadership is ability to influence a group toward the achievement goals. In this part who leads this institution is the headmaster [4]. This occupation has very important rule in educational institution. Because the headmaster can give instruction, guides, and also motivation to all staff. Everybody believe that an institution can develop well by his leadership. Good leadership not complete on corporate culture, but evolve. Communication is open daily [5]. Everyone recognizes the organization's vision and objective, and everyone has input on how to improve them. The leadership will determine the goal of the institution and of course it will happened when the leader can cooperate with all staffs, especially education staff [3]. As an education staff, not only about administrative task, but also many things that they do. Some phenomenon tells that education staff is not require special expertise. It makes someone who works as an education staff feel down and have no high work to serve in institution. It will affect the progress of Public Elementary School.

Education staff also has important rule in educational institution. In institution education staff who help teacher's works. The school or madrasah administrative staff consist of the head of staff administration of schools, business executor, and special service officer]. Education staff also has competency such as personality competence, social competence, technical competence, and managerial competence [6]. Education staff must have high work loyalty and able to work together with all personal in institution, because work together more easily then someone work by individual. In fact, every personnel in institution need education staff to help their task. In this situation, education staff need support from other personnel especially from the leader. Because the leader must be able to give motivation to education staff in order to do the task on time [7].

The headmaster of Public Elementary School applied unusual leadership pattern. The school principal embrace all school personnel to be involved in school activities. Although the existence of the principal is fairly new, the principal is able to make continuous changes to advance and improve the quality and service of the school. Although under the auspices of large institution such as Work Zone (Wilayah Kerja) and District Education, the head of the Public Elementary School remains creative and innovative in holding new programs that can improve the quality of school to the maximum extend such as conducting consultations [8].

The result some of research, show that, those examples from claiming sharpening one school principals, particularly state funded schools, has a tendency should be managerial Furthermore just actualize all the strategies starting with 
above, what is more may be not worried around if alternately not the approaches would in line with one school improvement focuses. The essential part for principals in encouraging what's more enhancing the execution about instructors what's more instruction work force ought to not main have the capacity on do managerial guidance, as well as have the capacity will create professionalism by enhancing the execution for educators what's more training work force [9]. Accordingly, those administration style of the central in an exertion will enhance those executions from claiming educators what's more instruction staff is exact fascinating on make utilized similarly as the keep tabs for scrutinize previously, depth, those analysts will behavior examination for "Principal initiative style on. Endeavors will move forward those executions of educators furthermore instruction personnel) "with the keep tabs from claiming Examine taken: (1) depict what's more examine those heading style of principals to an exert should enhance those executions for educators. With the focus of the research taken: 1) describing and analyzing the leadership style of principals effort to improve the performance of education staff at Public Elementary School; 2) Explore the factors that influence the leadership style of principals in Public Elementary School [10].

\section{METHOD}

The approach in this study is a descriptive qualitative approach with a case study design. Data sources in this study were obtained from data interviewers to informants and other data in the form of documentation or archives and photographs that support the main data.

According to Creswell [11], qualitative research is a methodology for investigating and understanding the significance people or gatherings credit to a social or human issue. The process of research involves emerging question and procedures, data typically collected in the participants setting, data analysis inductively building from particular to general themes, and the researcher making interpretation of the meaning of the data. The writer focus on qualitative design with the purpose to get information and data about leadership style of headmaster of Public Elementary School to improve education staff competence.

This study also explains how the writer get the data for to make the reader know about this study. Data collection is the process of collecting and measuring information on interesting factors by planning them in five fundamental steps; choosing respondents, obtaining authorization, selecting and weighing distinct kinds of data, designing recording protocol and managing data collection [5].

\section{RESULTS AND DISCUSSION}

The style of authority of the Head of Public Elementary School is that he is more subordinate. This shows that: (1) the styles of recognized vital power authorities begin with eight aspects, namely: (a) Daily behavioral techniques reveal the main needs for attention, discipline, initiative, openness, wisdom, bringing a sense of stability. The research findings are in accordance with several theories regarding leadership style. First the democratic leadership style menu Usman this leadership style encourages groups to discuss and participate. (g) Motivation by giving encouragement and fulfilling the needs of teachers and education staff. (h) The award given is in the form of praise and thanks that tries to be objective in praising and criticizing. So that the award given by the principal in the form of praise can influence the work spirit of the teacher and staff to continue to improve themselves [12].

In selecting leadership style there will be some components which influence. (2) The components are; (a) The headmaster experience in educational world who ever become high social teacher, give more motivation to another personnel to improve their ability. (b) A headmaster should have a good achievement, so it can motivate teachers and education staff in their institution for preparing competence students. (c) A headmaster should be able to become a role model for the teachers and education staff. if there are undisciplined personnel, directly headmaster should give right suggestion to that personnel. (d) A headmaster must be fair in giving some duties to each personnel and also giving guiding before. (e) Next factor is it also important create exciting atmosphere in institution, it can be make personnel more active and have a good work ship [13].

There are a lot of leadership style before. However, in this study focus on one of leadership style, that is Path leadership style to education staff. It determines this style from the action and behavior of headmaster in leading at Public Elementary School. Because, when the headmaster occurs in giving role model, motivation and also suggestion, it will influence the education staff work. Being a professional education staff is one of the effect from headmaster leadership style such as on time in doing the duty and having organized administration task [1].

\section{CONCLUSION}

From the discussion above the researcher can conclude:

1. The headmaster leadership style in Public Elementary School is Path Leadership. Because the headmaster mostly giving motivation to education staff, and suggestion before doing the task. It can make the education staff having more spirit to do the duty, being discipline to improve the ability.

2. The component of influence leadership style is; (a) the headmaster experience in educational world who ever become high social teacher, give more motivation to another personnel to improve their ability. (b) A headmaster should have a good achievement, so it can motivate teachers and education staff in their institution for preparing competence students. (c) A headmaster should be able to become a role model for the teachers and education staff. if there are undisciplined personnel, directly headmaster should give right suggestion to that personnel. (d) A headmaster must be fair in giving some duties to each personnel and also giving guiding before. (e) Next factor is it also important create exciting atmosphere in institution, it can be make personnel more active and have a good workship. 
Some principals, however, are not always efficient in their style of management when they do not involve to education staff in making significant decisions. In extremely performing schools that have reversed the trend of bad performance and decreasing performance, the headmaster sets the pace that leads and motivates education staff and all personnel to achieve their greatest potential [14]. Based on the explanation above headmaster of Public Elementary School using Path Leadership style in institution. Path leadership style has four basic types those are; role classification, supportive, participative, and autocratic. The implementation of Path Leadership style to improve education staff competence, having more spirit to the duty, and also increase the ability [3]. Because the headmaster give more motivation, as a role model for education staff and another personnel become discipline staff, fair with other personnel and crate exciting atmosphere in institution become have a good work ship [15].

\section{REFERENCES}

[1] P. G. Northouse, "Kepemimpinan: Teori dan praktik," Ed. Keenam. Jakarta Indeks, 2013.

[2] H. Usman, "Manajemen Teori, dan Riset pendidikan," Bumi Aksara Jakarta, 2014.

[3] C. M. Carson and J. E. King Jr, "Leaving leadership: Solving leadership problems through empowerment," Manag. Decis., vol. 43, no. 7/8, pp. $1049-1053,2005$.

[4] D. A. O. Aunga and O. Masare, "Effect of Leadership Styles on Teacher's Performance in Primary Schools of Arusha District Tanzania," dalam Int. J. Educ. Policy Res. Rev., vol. 4, no. 4, pp. 42-52, 2017.

[5] K. L. Webber, T. F. N. Laird, and A. M. BrckaLorenz, "Student and faculty member engagement in undergraduate research," Res. High. Educ., vol. 54, no. 2, pp. 227-249, 2013.

[6] L. Flanagan and M. Jacobsen, "Technology leadership for the twenty-first century principal," J. Educ. Adm., vol. 41, no. 2, pp. 124-142, 2003.

[7] A. Schutz, Innovations in Teacher Education: A Social Constructivist Approach, vol. 17, no. 1. 2008.

[8] L. M. Given, The Sage encyclopedia of qualitative research methods. Sage publications, 2008.

[9] H. M. Marks and S. M. Printy, "Principal leadership and school performance: An integration of transformational and instructional leadership," Educ. Adm. Q., vol. 39, no. 3, pp. 370-397, 2003.

[10]R. E. Slavin, "An introduction to cooperative learning research," in Learning to cooperate, cooperating to learn, Springer, 1985, pp. 5-15.

[11]J. W. Creswell and C. N. Poth, Qualitative inquiry and research design: Choosing among five approaches. Sage publications, 2017.

[12]K. H. Wruck and M. C. Jensen, "Science, specific knowledge, and total quality management," J. Account. Econ., vol. 18, no. 3, pp. 247-287, 1994.

[13] M. I. M. Hamzah, F. Juraime, and A. N. Mansor, "Malaysian Principals' Technology Leadership Practices and Curriculum Management," Creat. Educ., vol. 7, no. 07, p. 922, 2016.

[14]A. Walker, T. Bush, and G. K. T. Oduro, "New principals in Africa: preparation, induction and practice," J. Educ. Adm., 2006.

[15]F. M. Wachira, M. Gitumu, and Z. Mbugua, "Effect of Principals' Leadership Styles on Teachers' Job Performance in Public Secondary Schools in Kieni West Sub-County,”2017. 